\title{
Valuation of Provisioning Ecosystem Services Carat Cape Mangrove for Sungsang IV Village Community Banyuasin District
}

\author{
Ahmad Panandi ${ }^{*}$, Andy Mulyana ${ }^{2}$, Bernadette Robiani ${ }^{2}$ \\ ${ }^{1}$ Master Student at the Enviromental Management, Sriwijaya University, South Sumatera, Indonesia \\ ${ }^{2}$ Lecture at the Enviromental Management, Sriwijaya University, South Sumater, Indonesia \\ *Corresponding author: nandiesta@live.com
}

\begin{tabular}{llll} 
Article history & & & \\
\hline Received & Received in revised form & Accepted & Available online \\
30 June 2019 & 10 December 2019 & 27 December 2019 & 30 December 2019 \\
\hline
\end{tabular}

\begin{abstract}
Mangrove ecosystem valuation can be used as a reference for decision making for management and conservation of mangrove ecosystems in a sustainable manner. The range of activities and interests conducted in coastal areas is not expected to negatively impact the ecology, economic and social. Carat Cape mangrove areas provide enormous benefits to the surrounding community, especially Sungsang IV village. From the results of the study illustrate the provosioning ecosystem service utilized community Sungsang IV village consists of materials construction (timber and nypa leaves), a source of livelihood or subsistance (nypa fruit, fish, shrimp, crab, and scallops). The total value of provosioning ecosystem services mangrove Carat Cape utilized by 45 respondent the Sungsang IV village community Rp. Rp.1.715.590.000, - per year dominated by income generated by marine of fisheris which is the main livelihood of the fishermen Sungsang IV village reached Rp.1.302.600.000,- per year on 2018.
\end{abstract}

Keyword: Provisioning Services, Mangrove, Ecosystem services, Sungsang IV.

Abstrak (Indonesian): Penilaian ekosistem mangrove dapat dijadikan sebagai acuan pengambilan keputusan untuk pengelolaan pelestarian ekosistem mangrove secara berkelanjutan. Berbagai kegiatan dan kepentingan yang dilakukan di wilayah pesisir diharapkan tidak memberikan dampak negatif terhadap aspek lingkungan, ekonomi dan sosial. Kawasan hutan mangrove Tanjung Carat memberikan manfaat yang sangat besar terhadap masyarakat sekitar terutama Desa Sungsang IV. Dari hasil penelitian menggambarkan jasa lingkungan penyedia yang dimanfaatkan masyarakat Desa Sungsang IV terdiri dari bahan bangunan (kayu hutan dan daun nipah), sumber mata pencaharian atau pangan (buah nipah, ikan, udang, kepiting, dan kerang). Total nilai jasa lingkungan penyedia dari hutan mangrove Tanjung Carat yang dimanfaatkan oleh 45 responden masyarakat Desa Sungsang IV sebesar Rp. Rp.1.715.590.000,- per tahun di dominasi dengan pendapatan hasil laut perikanan yang merupakan mata pencaharian utama nelayan Desa Sungsang IV mencapai Rp.1.302.600.000,- per tahun pada tahun 2018.

Kata Kunci: Jasa Lingkunan penyedia, hutan mangrove, jasa lingkungan, Desa Sungsang IV.

\section{Introduction}

The mangrove is one form of forest ecosystems are unique and distinctive, has a high economic and ecological, but very susceptible to damage if undiplomatic in its management[1]. The existence of mangrove which is a resource that can be recovered has provided benefits to the community are mostly in coastal areas[2].

The mangrove ecosystem has a component of natural resources in the form of landscapes, flora, fauna, and local communities interact with each other into one unified ecosystem function ecologically, economically and socially important in the development of coastal areas[3]. This ecosystem is well known for its enviromental connotation, and it is significant for storm/flood protection, the biodiversity maintanance, habitat provision, erosion control, nutrient recycling, and waste treatment services. Additionally millions of people depend on this ecosystem daily livelihood and subsistence[4].
Ecosystem services are the benefits people obtain from the ecosystem functions that have direct and indirect benefits to human life[5]. The ability to calculate the economic value of the ecosystem goods and services is increasingly recognized necessary condition for integrated enviromental decision-making, sustainable business practice, and land-use planning at multiple geographic scales and socio-political level[6]. These ecosystem services are divided into four broad categories, provisioning, regulating, supporting and cultural services[7].

The range of activities and interests held in the coastal areas, sometimes even contradictory. Conflicts occur space utilization, because there are no clear rules on coastal spatial planning can be used as a reference of the various sectors concerned. Development issues which often arise coastal areas namely previously make a significant contribution to the national economic development of the use of the resource potential of huge potential. In fact, environmental 
degradation has occurred in some coastal areas as a result of the use of which does not consider the environmental carrying capacity [8].

Although it is estimated to be more profitable than the economic aspects of regional income mainly on the development of Carat Cape function of mangrove, but directly or indirectly will have an impact, especially to the people who rely Sungsang IV village livelihood to the utilization of ecosystem services mangrove Carat Cape.

This study aims to identify and calculate the value of ecosystem services mangrove Carat Cape are included in the special economic zone development plan. The benefits of this research is expected to become a reference in the implementation of mangrove management policies Carat Cape as well as being a comparison between mangrove ecosystem services post-construction with pre-development a special economic zone of mangrove of Carat Cape later.

\section{Methods}

\subsection{Methods}

This research was conducted in January untill April 2019 in the Sungsang IV village of Banyuasin District. Mangrove of Carat Cape is administratively part of the Sungsang IV village area at Banyuasin II Region Banyuasin District.

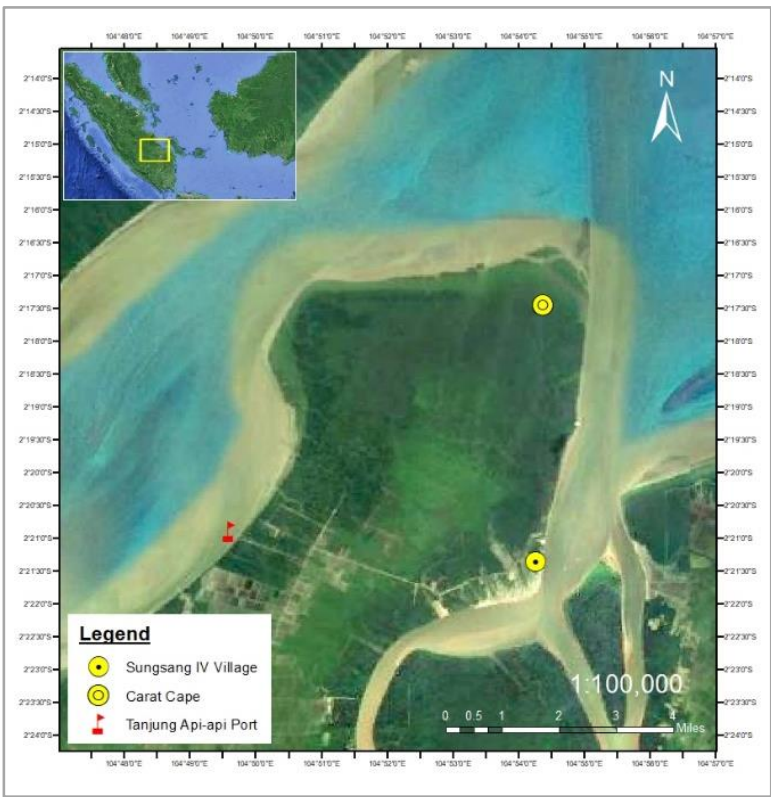

Figure 1. Map of the study area

Data collected in the form of primary data and secondary data, primary data obtained through interviews using a questionnaire to the village community Sungsang IV per household. While the secondary data such as demographic data, biophysical mangrove condition data, the data about the profile of the village, socio-economic collected through the study of literature from reports of implemented activities related local governments as well as the results of research that has been done at the sites. The sampling method in this research is done in a non-probability with purposive sampling method, that is done deliberately by the consideration that the respondents are community Sungsang IV village who understand and know the condition of mangrove Carat Cape.

\subsection{Data Analysis}

Determination of the number of respondents in this study using a minimum sample size formula Slovin $^{[9]}$.

$$
\begin{aligned}
& \mathrm{n}=\frac{\mathrm{N}}{\left[1+\mathrm{N}(\mathrm{e})^{2}\right]} \\
& \mathrm{n}=\frac{1586}{\left[1+1586(0.15)^{2}\right]} \\
& \mathrm{n}=44,416
\end{aligned}
$$

\section{Information : \\ $n \quad=$ Number of samples (Respondents) \\ $N \quad=$ Population Total (Household) \\ $e \quad=$ Margin of error $15 \%$ \\ $1=$ Constant Numbers}

Sungsang IV village consisted of 1,586 household according to data cited from the Central Agency of Statistics Banyuasin 2018[10]. Thus the number of samples that will be the respondent in this research amounted to 45 household.

Identification of provisioning ecosystem services mangrove Carat Cape are using descriptive methods based on the Millennium Ecosystem Assessment[11] which defines ecosystem services as benefits derived from ecosystems. Millenium Ecosystem Assessment divides ecosystem services into four categories, namely provisioning services, supporting services, regulatory services, and cultural services. The definition of provisioning ecosystem services include; food, fiber, fuel, genetic resources, biochemical, resources, and fresh water.

The value of the provisioning ecosystem services is determined by their local market price on 2019. Formulation of the market price for provisioning services based on KLH[12].

$$
\mathrm{DUV}_{\mathrm{i}}=\left(\mathrm{Hp}_{\mathrm{i}} \cdot \mathrm{P}_{\mathrm{i}} \cdot \mathrm{JN}_{\mathrm{i}}\right)-\mathrm{Bp}_{\mathrm{i}}
$$

$$
\begin{aligned}
& \text { ( } \mathrm{kg} / \text { year/person) } \\
& \text { JNI = Number of commodity } i \text { (Person) } \\
& \mathrm{Bpi}=\text { Cost of production of commodities }(\mathrm{Rp}) \\
& i \quad=\text { Type Commodity }
\end{aligned}
$$

\section{Results and Discussion}

Ecosystem valuation is an approach to assign monetary values to an ecosystem and its key ecosystem goods and services, generally referred to as Ecosystem Service Value ${ }^{[4]}$. Recent comprehensive approaches to assessing the interface between 
biophysical as well as ecological processes and the livelihood of coastal communities have updated our view of the value of mangrove goods and services [13].

Access to provisioning ecosystem services or the ability to benefit from provisioning ecosystem services is essential for the wellbeing of ecosystem dependent communities ${ }^{[14]}$. Provisioning ecosystem services Carat Cape mangrove include forest products; Wood materials, nypa leaves as a material construction, nypa fruit as food, and seafood; fish, shrimp, crabs and shellfish as a source of livelihood (table 1).

Table 1. Provisioning ecosystem services form mangrove Carat Cape by Sungsang IV village.

\begin{tabular}{|c|c|c|}
\hline $\begin{array}{l}\text { Ecosystem } \\
\text { Services }\end{array}$ & Local name & Species \\
\hline Wood & $\begin{array}{l}\text { Tomo, } \\
\text { Jangkang }\end{array}$ & $\begin{array}{l}\text { Bruguiera } \\
\text { gimnorrhiza, } \\
\text { Rhizophora sp. }\end{array}$ \\
\hline Nipah leaf & Nipah & Nypa fruticans \\
\hline $\begin{array}{l}\text { Nipah } \\
\text { fruit }\end{array}$ & Nipah & Nypa fruticans \\
\hline Fish & $\begin{array}{l}\text { Pari, } \\
\text { Sembilang, } \\
\text { Gelame, dll }\end{array}$ & $\begin{array}{l}\text { Dasyatis sp., } \\
\text { Plotosus canius, } \\
\text { Mugil voigiensis }\end{array}$ \\
\hline Shrimp & $\begin{array}{l}\text { Udang } \\
\text { Burung }\end{array}$ & $\begin{array}{l}\text { Panaeus } \\
\text { merguensis }\end{array}$ \\
\hline $\begin{array}{l}\text { Crab } \\
\text { Scallops }\end{array}$ & $\begin{array}{l}\text { Rajungan } \\
\text { Lokan }\end{array}$ & $\begin{array}{l}\text { Portunus pelagicus } \\
\text { Geloina erosa }\end{array}$ \\
\hline
\end{tabular}

There are several studies that resemble this study for example Idrus et al[2], valuated ecosystem services mangrove in Jaililo District, West Halmahera Regency. Valuation provosioning ecosystem services (wood, fish and crabs) namely Rp. 16.960.000,- per year. Or Uddin et al[15]. valuated of the provisioning ecosystem services mangrove (Wood, firewood, fish, straw, and honey) in Bangladesh. Source of data to identify ecosystem from local forestry agency. His research uses average ecosystem services utilized from 2001 to 2010 with valuation average of US\$ 744,000 per year.

After identification, provisioning ecosystem services from Tanjung Carat mangrove consisting of forest products (wood, palm leaves and nipah fruits) and marine products (fish, shrimp, crabs and shellfish) utilized by the Sungsang IV village community are valuation shown in table 2 .
Table 2. Valuation of provisioning ecosystem services from Mangrove Carat Cape by Sungsang IV village.

\begin{tabular}{|c|c|c|c|}
\hline & Ecosystem services & Unit & Value \\
\hline \multicolumn{4}{|c|}{ Wood } \\
\hline (a) & Price & $\mathrm{Rp} / \log$ & 25,000 \\
\hline (b) & Production & $\log / y r$ & 30 \\
\hline (c) & $\begin{array}{l}\text { Fishermen } \\
\text { (Percentage) }\end{array}$ & person & $6(13.3 \%)$ \\
\hline (d) & Production cost & $\mathrm{Rp} / \mathrm{yr}$ & 300,000 \\
\hline & Total (a) (b) - (d) & $\mathrm{Rp} / \mathrm{yr}$ & 450,000 \\
\hline
\end{tabular}

Nypa Leaf

\begin{tabular}{|c|c|c|c|}
\hline (a) & Price & Rp/pieces & 3,500 \\
\hline (b) & Production & pieces/yr & 2,540 \\
\hline (c) & $\begin{array}{l}\text { Fishermen } \\
\text { (Percentage) }\end{array}$ & person & $9(20 \%)$ \\
\hline (d) & Production cost & $\mathrm{Rp} / \mathrm{yr}$ & $3,810,000$ \\
\hline & Total (a) (b) - (d) & $\mathrm{Rp} / \mathrm{yr}$ & $5,080,000$ \\
\hline
\end{tabular}

Nypa fruit

\begin{tabular}{|c|c|c|c|}
\hline (a) & Price & $\mathrm{Rp} / \mathrm{Can}$ & 7,000 \\
\hline (b) & Production & $\mathrm{Can} / \mathrm{yr}$ & 1,140 \\
\hline (c) & $\begin{array}{l}\text { Fishermen } \\
\text { (Percentage) }\end{array}$ & person & $2(4.4 \%)$ \\
\hline (d) & Production cost & $\mathrm{Rp} / \mathrm{yr}$ & $1,440,000$ \\
\hline & Total (a) (b) - (d) & $\mathrm{Rp} / \mathrm{yr}$ & $6.540,000$ \\
\hline \multicolumn{4}{|c|}{ Fish } \\
\hline (a) & Price & $\mathrm{Rp} / \mathrm{kg}$ & 25,000 \\
\hline (b) & Production & $\mathrm{kg} / \mathrm{yr}$ & 95,160 \\
\hline (c) & $\begin{array}{l}\text { Fishermen } \\
\text { (Percentage) }\end{array}$ & person & $11(24.4 \%)$ \\
\hline (d) & Production cost & $\mathrm{Rp} / \mathrm{yr}$ & $1,076,400,000$ \\
\hline & Total (a) (b) - (d) & $\mathrm{Rp} / \mathrm{yr}$ & $1,302,600,000$ \\
\hline
\end{tabular}

Shrimp

\begin{tabular}{|c|c|c|c|}
\hline (a) & Price & $\mathrm{Rp} / \mathrm{kg}$ & 60,000 \\
\hline (b) & Production & $\mathrm{kg} / \mathrm{yr}$ & 7,592 \\
\hline (c) & $\begin{array}{l}\text { Fishermen } \\
\text { (Percentage) }\end{array}$ & Person & $6(13.3 \%)$ \\
\hline (d) & Production cost & $\mathrm{Rp} / \mathrm{yr}$ & $182,000,000$ \\
\hline & Total (a) (b) - (d) & $\mathrm{Rp} / \mathrm{yr}$ & $273,520,000$ \\
\hline \multicolumn{4}{|c|}{ Crab } \\
\hline (a) & Price & $\mathrm{Rp} / \mathrm{kg}$ & 45,000 \\
\hline (b) & Production & $\mathrm{kg} / \mathrm{yr}$ & 2,080 \\
\hline (c) & $\begin{array}{l}\text { Fishermen } \\
\text { (Percentage) }\end{array}$ & Person & $2(4.4 \%)$ \\
\hline (d) & Production cost & $\mathrm{Rp} / \mathrm{yr}$ & $31,200,000$ \\
\hline & Total (a) (b) - (d) & $\mathrm{Rp} / \mathrm{yr}$ & $62,400,000$ \\
\hline
\end{tabular}

Scallop

\begin{tabular}{llcc} 
(a) & Price & $\mathrm{Rp} / \mathrm{kg}$ & 1,500 \\
(b) & Production & $\mathrm{kg} / \mathrm{yr}$ & 52,000 \\
(c) & Fishermen & Person & $1(2.2 \%)$ \\
(d) & Production cost & $\mathrm{Rp} / \mathrm{yr}$ & $13,000,000$ \\
\hline & Total (a) (b) - (d) & $\mathrm{Rp} / \mathrm{yr}$ & $65,000,000$ \\
\hline
\end{tabular}


Sungsang IV village utilize timber for materials construction. However, with the ban on logging in the forest by the forest department, only a small portion of society which utilizes wood provisioning ecosystem services. Only 6 respondents who use the timber to house additional poles of mangrove pole size $10-15 \mathrm{~cm}$ in diameter with a length of 4-5 meters with a value of ecosystem services 450.000 ,- per year. To obtain the timber, the public must first request permission from the village, then the falling system is done by spacing each tree to be felled spread out.

The mangrove palm Nypa fruticans is commonly used for the production of thatch, beverage, sugar, alcohol and vinegar in Southeast Asia[16]. Nypa leaves are used as roofs and walls of houses that were previously processed first by the local people so that a ready-made pieces. The use of nypa leaves in the Sungsang IV village amount varies with the needs of home building. The use of nypa leaf material of 2.540 pieces per year with a value of Rp. 5.080.000, - per year.

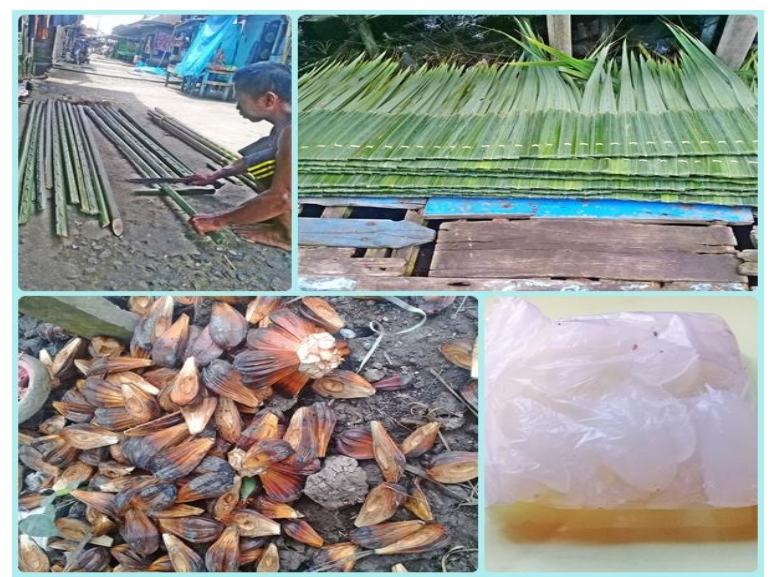

Figure 2. Provisioning ecosystem service for nypa leaves and fruit by Mangrove Carat Cape

Nypa fruit can be consumed directly or processed into other confectionary by Sungsang IV society. There were two respondents who use nypa fruit as a livelihood by selling directly to the surrounding community. The highest demand nypa fruit sales occurred in the fasting month. Total utilization of palm fruit of two respondents is 1.140. cans per year. Sales of nypa fruit for Rp. 7.000,- per cans with a volume of $305 \mathrm{~cm}^{3}$ each canister.

The South China Sea, close to the Sumatran coast and the Strait of Bangka, is a highly productive ecosystem owing to the shallow conditions (less than $30 \mathrm{~m})$ and the continuous input of nutrient rich sediments from the discharge of the Musi and Banyuasin Rivers[17]. The results obtained from the sea around the of Carat Cape in the form of fish, shrimp, crabs and scallops. However, most people find fish further Sungsang which takes a week to a month at sea. The advantage for fish around Carat Cape will be more efficient in terms of distance and time so that the
Sungsang IV village who sail around the Carat Cape round fishing per day. Besides the ship used ship measuring about 5-12 GT. Marine fish is the most high value ecosystem services is Rp. 1.302.600.000,- per year results of 11 samples of fishing with a total production of $95,160 \mathrm{~kg}$ per year.

Ecosytem service mangrove shrimp and crab Carat Cape seasonal effect. For shrimp season is usually around 4 months per year while the crab about two months per year. Catching shrimp and crab using gear types that separate nets for shrimp fishing nets and bag nets mud crab special mangrove. Utilization of shrimp in one year amounted to $7.592 \mathrm{~kg}$ total of 6 shrimp fisherman with a value of Rp. 273.520.000,per year at a price of shrimp Rp. 60.000 , - per kg. Furthermore, there are 2 samples of crab fisherman with total utilization of $2.080 \mathrm{~kg}$ so that the value of ecosytem services for the crab Rp. 62.400.000,- per year.

There is a small fraction of the Sungsang IV utilizing provisioning ecosystem services is scallops. Utilization of shells can be done every day, but the scallop fishermen switch for crabs when crab season for 2 months. The average yield of 200 quintals of mussels per day resulted in a value of Rp ecosystem services. 65.000.000,- per year with the search period for 10 months per year.

Table 3. Total of provisioning ecosystem services by Mangrove Carat Cape.

\begin{tabular}{lc}
\hline \multicolumn{1}{c}{$\begin{array}{c}\text { Environmental } \\
\text { services }\end{array}$} & $\begin{array}{c}\text { Value } \\
\text { (Rp per year) }\end{array}$ \\
\hline Wood & 450,000 \\
Daun Nipah & $5,080,000$ \\
fruit Nipah & $6,540,000$ \\
Fish & $1,302,600,000$ \\
Shrimp & $273,520,000$ \\
Crab & $62,400,000$ \\
Shell & $65,000,000$ \\
\hline \multicolumn{1}{c}{ Total } \\
\hline
\end{tabular}

Total provisioning ecosystem services mangrove Carat Cape is Rp. 1.715.590.000,- per year, with details as shown in Table 3.

\section{Conclusions}

Based on the results of the valuation provisioning ecosystem services Carat Cape by 45 respondent has a value of ecosystem services Carat Cape headland region is Rp. 1.715.590.000,- per year dominated by income generated by marine species of fish which is the main livelihood of the fishermen Sungsang IV village reached Rp. 1.302.600.000,- per year. It is expected the development of a special economic zone of mangrove of Carat Cape did not 
leave a significant negative impact that will threaten ecosystems and livelihoods around.

\section{References}

[1] A. M. Zainuri, A. Takwanto, and A. Syarifuddin, "Conservation of Mangrove Ecolgy at Mayangan Districk Probolinggo City," Dedication Journal, vol. 14, pp. 1-7, 2017.

[2] S. Idrus, A. Ismail, and M. Ekayani, "Potency of Payment for Environmental Services of Mangrove Forest in Sub-district of Jailolo of West Halmahera District," Jurnal Ilmu Pertanian Indonesia, vol. 21, no. 3, pp. 195-202, 2016.

[3] M. K. Wardhani, "Mangrove conservation area: a potential of ecowisata," Ocean Journal, vol. 4, no. 1, pp. 60-76, 2011.

[4] S. Sannigrahi et al., "Ecosystem service value assessment of a natural reserve region for strengthening protection and conservation," $J$ Environ Manage, vol. 244, pp. 208-227, Aug 15 2019.

[5] A. Rachdian, L. B. Prasetyo, and S. B. Rushayati, "Identification of Environmental Services Cahnges Using Remote Sensing and Geographic Information System in Bogor," Media Konservasi, vol. 21, no. 1, pp. 48-57, 2016.

[6] Q. T. Vo, C. Kuenzer, Q. M. Vo, F. Moder, and N. Oppelt, "Review of valuation methods for mangrove ecosystem services," Ecological Indicators, vol. 23, pp. 431-446, 2012.

[7] W. W. Y. Lau, "Beyond carbon: Conceptualizing payments for ecosystem services in blue forests on carbon and other marine and coastal ecosystem services," Ocean \& Coastal Management, vol. 83, pp. 5-14, 2013.

[8] R. Lasabuda, "Regional Development in Coastal and Ocean in Archipelago Perspective of The Republic of Indonesia," Jurnal Ilmiah Platax, vol. 1-2, pp. 92-101, 2013.

[9] J. Harlan, Calculation of Sample Size, Power and Effect Size. Depok: Penerbit Gunadarma, 2017.

[10] B. P. S. K. Banyuasin, Banyuasin District II in Figures 2018. Banyuasin: BPS Kabupaten Banyuasin, 2018.

[11] M. E. Assessment, Ecosystem and Human WellBeing: Synthesis. Washington DC: Island Press, 2005.

[12] Regulation Of The Minister Of State Environment Of The Republic Of Indonesia, E. M. O. T. R. Indonesia 15, 2012.

[13] J. H. Primavera, D. A. Friess, H. Van Lavieren, and S. Y. Lee, "The Mangrove Ecosystem," pp. 134, 2019.

[14] A. S. M. G. Kibria, R. Costanza, C. Groves, and A. M. Behie, "The interactions between livelihood capitals and access of local communities to the forest provisioning services of the Sundarbans Mangrove Forest, Bangladesh," Ecosystem Services, vol. 32, pp. 41-49, 2018.
[15] M. S. Uddin, E. de Ruyter van Steveninck, M. Stuip, and M. A. R. Shah, "Economic valuation of provisioning and cultural services of a protected mangrove ecosystem: A case study on Sundarbans Reserve Forest, Bangladesh," Ecosystem Services, vol. 5, pp. 88-93, 2013.

[16] S. Baba, H. T. Chan, and S. Aksornkoae, Useful Products From Mangrove and Other Coastal Plants. Okinawa: In ISME Mangrove Educational Book Series, 2013.

[17] W. J. M. Verheugt, A. Purwoko, F. Danielsen, H. Skov, and R. Kadarisman, "Integrating mangrove and swamp forest conservation with coastal lowland development; the Banyuasin Sembilang swamps case study, South Sumatra Province, Indonesia," Landscape and Urban Planning, vol. 20, pp. 85-94, 1991. 